\title{
Development of a Service Framework for Library Users from Customer Relationship Management Perspective
}

\author{
Shiow-Luan Wang \\ Department of Information Management, National Formosa University, \\ Huwei, Yunlin, Taiwan, \\ R.O.C.
}

\section{Introduction}

Libraries are service organizations that store data and function as main information resource centers for various users (Hernon and Altman, 1998; Hernon and Calvert, 2005; Huang, 2007; Raza and Nath, 2007). Traditionally, users go to the library for services, such as borrowing/returning books, accessing the reference directory, availing of interlibrary loans and document delivery, and browsing through relevant collections of resources. At present, many library service features have changed due to the recent developments in digital and networked environment technologies. The ubiquity of the Internet has been used extensively in many libraries, generating a profound effect on library users.

University library users include authorized faculty, undergraduate and graduate students, staff, and project/contract assistants. Given that there are different kinds of library users in any University setting, a barrier certainly exists in overcoming the one-to-one relationship model for each user. Library professionals confirm the difficulties involved in providing training for their students because of the large number of students, lack of suitable training rooms and equipment, and the shortage of qualified trainers (Bex and Miller, 1999). Moreover, library users are considered as customers, and taking note of their opinions may ensure the succession of a library in terms of service delivery. According to Huang (2007), library service is a kind of invisible product; thus, it is important to obtain user feedback in improving the service being provided. However, there is still no clear definition of who library users are and how to transform a library user-oriented service model to make it similar to a customer-based one.

This study aims to define users as customers and develop a conceptual framework from a customer relationship management (CRM) perspective. The inclusion of organizational capability can lead to a more successful administrative management, and this framework can be applied to academic library service in order to further improve user service. In the present work, the library organizational capability is also explored.

\subsection{Library service}

Numerous studies have reported that library service is user-oriented; thus, it is important to meet the demands and expectations of users (Ojala, 1986; Millson-Martula and Menon, 1995; 
Nitecki, 1996; Johnson and MacEwan, 1999; Flanagan and Horowitz, 2000; Cullen, 2001; Shi, et al, 2004; Huang, 2007). In recent years, the proliferation of information communication technology (ICT) has made it possible to address the needs of users for timelier as well as more convenient and rapid information delivery. In addition, the application of ICT helps libraries identify the needs of their users and provide correct information by utilizing plenty of resources. Libraries play an interactive role in encouraging users to utilize their resources, thus establishing a relationship with such users (Fig. 1).

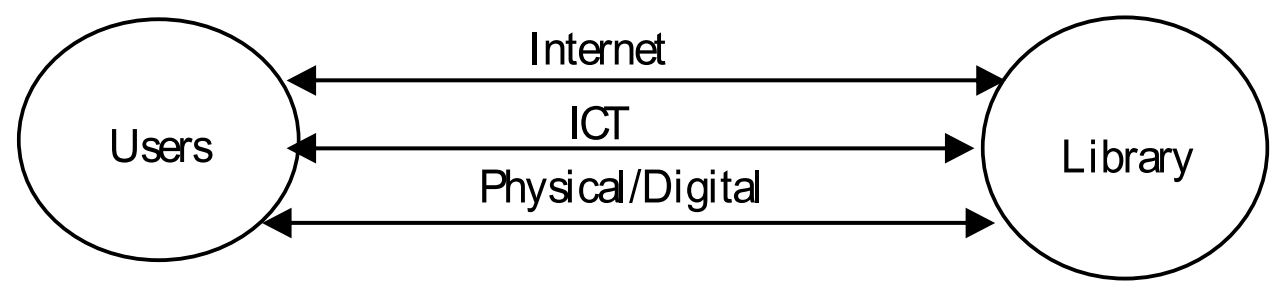

Fig. 1. Two-way connection between users and the library

Toward the goal of servicing users effectively and efficiently, many libraries provide activities, such as simultaneous remote access in multiple databases, seamless linking to database resources, selection of favorite resources and e-journals, setting up email alerts, and so on. In the information era, the Internet and ICTs have had great impact on the development of printed and electronic resource collection. To avoid existing issues on electronic resources, the proposed CRM helps library managers review their service strategies and promote the value of using the library in the university. The concept is similar to how CRM is used to generate business profits when applied in e-Commerce.

\subsection{Customer relationship management initiative}

Many library managers believe that library operation and service development is customer focused. Generally, CRM is used to analyze and utilize marketing databases as well as to leverage communication technologies in order to determine corporate practices and methods to maximize the lifetime value of each individual customer to the organization (Kumar and Reinartz, 2006). In the application of CRM in library service, library managers can focus on how they can arrange their collections and services to attract more users to the library. Thus, it has become their top priority to determine how customers expect to use a library. A relationship is a bond or connection between an organization and its customer (Mohammed et al., 2002). Researchers have used the following to emphasize the application of CRM issues in the library: data mining on book recommendation and library marketing (Yen, 2002); resource usage efficiency (Chen et al., 2004); acquisition budget allocation (Kao et al., 2003); acquisition and cataloging (Chu, 2005); improving service (Will, 2006); user service (Wang, 2006); and CRM software in e-journal access (Borchert, 2006). Without appropriate CRM, a library manager may misunderstand users' service requests and be unable to meet user expectations.

Recently, researchers have focused on the concept of personalization or personalized service (Bielema et al., 2007; Frias-Martinez et al., 2006; Fan et al., 2005; Renda \& Straccia, 2005; Giacomo et al., 2004; Hicks, 2003; Jurewicz \& Cutler, 2003). Libraries provide a 
communicational channel (i.e., Libweb), through which users can ask for a service; however, this is a passive solicitation of feedback. Personalized service focuses on being "better, faster, and cheaper" as expressed in modern management practices (Cardwell et al., 2001). Meanwhile, some libraries have established liaison outreach programs to know users better by providing greater amount of information about library programs and services (MillsonMartula and Menon, 1995).

\section{Related studies}

\subsection{Library service development}

A user is the key subject and the first to be defined due to his/her association with library operation and development. In the 1980s, library users were regarded as end-users, and Ojala was the first to propose in 1986 that libraries treat users as customers and must be able to meet their demands should. Considering the importance of users to libraries, researchers have proposed that library management consider user needs as well as customer expectation and satisfaction in setting management goals (Green, 1990; Millson-Martula and Menon, 1995; Heckart, 1999; Hernon et al., 1999; Flanagan and Horowitz, 2000; Cullen, 2001; Martensen and Gronholdt, 2003; Shi et al., 2004). Since the emergence of a network environment, libraries have to pay close attention to their customers' opinions (Cullen, 2001; Van Groenendaal, 1997; Xie, 2006; Koohang and Ondracek, 2005). Users have their own library service requirements in the same way that they make demands as consumers in the realm of business. In this context, the Internet offers an unprecedented opportunity for personalized customer services (Heckart, 1999). Additionally, a one-to-one marketing paradigm provides an organization with the opportunity to engage customers in interactive communication using ICTs as the enabling factors (Wells et al., 1999).

\subsection{User expectations and satisfaction}

The effects of satisfaction and quality improvement efforts on customer retention and market share have been studied by Payne and Frow (2005). The loyalty acquired from users represents a significant effect of library service. Previous works have also reported findings regarding user needs, customer expectations, and satisfaction (Table 1).

Satisfying customer expectations and caring for their individual needs require a thorough understanding of how they are related to CRM. Customer satisfaction represents the degree to which a library has met the user's needs and expectations (Cooper and Dempsey, 1998:33; Dlamini, 2006). User satisfaction is equal to success, although complaints may still exist (Oh, 2003; 2004). One way of ensuring satisfaction is to encourage users to utilize the resources and services offered by libraries. Libraries can also implement instruction programs to educate and guide users in browsing through the resources.

\subsection{Library instruction}

Instructional effectiveness by assessing learning outcomes includes positive cognitive, behavioral, and effective results (Julien and Boon, 2004). Nowadays, students no longer learn using the same modes during the time of printed resource materials (Wen et al., 2008). In fact, students nowadays are born in the so-called "net generation" (Zimmerman and 


\begin{tabular}{|c|c|c|}
\hline Authors and year & Main findings & Conclusions \\
\hline Phipps (2001) & $\begin{array}{l}\text { A danger in the shift of resource } \\
\text { allocation and customer loyalty }\end{array}$ & $\begin{array}{l}\text { Integrate feedback from } \\
\text { customers }\end{array}$ \\
\hline Cullen (2001) & Difficult to retain customers & Improve customer satisfaction \\
\hline $\begin{array}{l}\text { Keating and Hafner } \\
(2002)\end{array}$ & $\begin{array}{c}\text { Systems do not provide } \\
\text { sufficient information when } \\
\text { multiple patrons share the same } \\
\text { login/password }\end{array}$ & $\begin{array}{l}\text { Develop the strategy of one-to- } \\
\text { one relationship management }\end{array}$ \\
\hline $\begin{array}{l}\text { Martensen and } \\
\text { Gronholdt (2003) }\end{array}$ & Lack of human service & $\begin{array}{l}\text { Provide friendly, helpful, and } \\
\text { professional guidance }\end{array}$ \\
\hline Keng (2003) & $\begin{array}{c}\text { Lack of appropriate interaction, } \\
\text { absence of goals and } \\
\text { communication }\end{array}$ & $\begin{array}{l}\text { Identify segments of } \\
\text { customers }\end{array}$ \\
\hline Shi et al. (2004) & $\begin{array}{l}\text { Satisfaction with the } \\
\text { information product received } \\
\text { and the information system } \\
\text { used to retrieve the product }\end{array}$ & $\begin{array}{l}\text { Provide a well-developed } \\
\text { library management method }\end{array}$ \\
\hline Dlanmini (2006) & $\begin{array}{l}\text { Lack of proper methods and } \\
\text { strategies in dealing with } \\
\text { customer care }\end{array}$ & $\begin{array}{l}\text { Develop identified customer } \\
\text { care strategies, such as } \\
\text { technology, utility call centers }\end{array}$ \\
\hline $\mathrm{Wu}(2007)$ & $\begin{array}{l}\text { Most of the users know little } \\
\text { about e-resources, } \\
\text { undergraduate students prefer } \\
\text { to obtain printed documents }\end{array}$ & $\begin{array}{l}\text { Recognize that teachers' and } \\
\text { students' needs for e-resources } \\
\text { are different }\end{array}$ \\
\hline
\end{tabular}

Table 1. Summary of previous findings on user needs, expectations, and satisfaction 
Milligan, 2007) or "Google generation" (Sykes, 2007). Wu (2007), however, reports that the overwhelming majority of the students know little about electronic resources and $49.6 \%$ of all college students in the study preferred printed periodicals. Researchers have suggested alternative methods to help users (Jiao et al., 1996; Onwuegbuzie, 1997; Jerabek, 2001). Various studies have reported that university libraries have established instruction programs in collaboration with the faculty so as to provide interactive instructions for improving the students' information search capabilities (Table 2).

\begin{tabular}{|c|c|c|}
\hline Authors and year & Main Findings & Conclusions \\
\hline Sinn (1998) & $\begin{array}{l}\text { Introduced students to the resources to } \\
\text { help them complete their assignment. }\end{array}$ & \multirow{6}{*}{$\begin{array}{l}\text { Libraries establish programs } \\
\text { in collaboration with teaching } \\
\text { faculty in the class. }\end{array}$} \\
\hline Sinn (2000) & $\begin{array}{c}\text { The use of databases and the World } \\
\text { Wide Web are differences between } \\
\text { magazines and journals. }\end{array}$ & \\
\hline Lawson (2000) & $\begin{array}{l}\text { Needs for meeting the } \\
\text { information literacy of today's college } \\
\text { students }\end{array}$ & \\
\hline Hinchliffe (2000) & $\begin{array}{l}\text { The term papers produced have been } \\
\text { improved by the guided research } \\
\text { process. }\end{array}$ & \\
\hline $\begin{array}{l}\text { Webster and Rielly } \\
\text { (2003) }\end{array}$ & $\begin{array}{l}\text { Library instruction is time- and labor- } \\
\text { intensive, especially for new courses. }\end{array}$ & \\
\hline Sanborn (2005) & $\begin{array}{l}\text { Library instruction is improved with } \\
\text { learning outcomes when combined with } \\
\text { faculty cooperation. }\end{array}$ & \\
\hline Olson (2000) & $\begin{array}{l}\text { Promote students' self-confidence and } \\
\text { encourage them to freely assess and } \\
\text { evaluate the sources of information they } \\
\text { find. }\end{array}$ & \multirow{3}{*}{$\begin{array}{l}\text { Classrooms have become } \\
\text { more interactive, one-on-one } \\
\text { instruction and information } \\
\text { search is increasing after the } \\
\text { instruction training. } \\
\text { The impact of library } \\
\text { instruction leads to user } \\
\text { satisfaction. }\end{array}$} \\
\hline Ren (2000) & $\begin{array}{l}\text { The increase has been related to } \\
\text { attitudes, emotional experiences, and } \\
\text { search performance. }\end{array}$ & \\
\hline Lapidus (2003) & $\begin{array}{l}\text { The electronic resources and online } \\
\text { bibliographic instruction for future } \\
\text { medical professionals is important. }\end{array}$ & \\
\hline Vander (2000) & $\begin{array}{l}\text { Evaluation has been conducted } \\
\text { successfully by libraries in the form of } \\
\text { focus groups, pilot-testing, tracking } \\
\text { usage of web pages, and surveys. }\end{array}$ & \multirow{2}{*}{$\begin{array}{c}\text { Enhance Web-based } \\
\text { instruction for a student } \\
\text { interacting with the library. }\end{array}$} \\
\hline Ragains (2001) & $\begin{array}{l}\text { Student response to incorporating this } \\
\text { type of Web page into library } \\
\text { instruction. }\end{array}$ & \\
\hline $\begin{array}{l}\text { Portmann and Roush } \\
\qquad(2004)\end{array}$ & $\begin{array}{c}\text { Libraries are being held increasingly } \\
\text { accountable for assessing learning } \\
\text { outcomes and addressing research } \\
\text { design issues. }\end{array}$ & \multirow[t]{2}{*}{$\begin{array}{l}\text { Design valid assessment } \\
\text { programs and accurate } \\
\text { documentation of student } \\
\text { learning. }\end{array}$} \\
\hline Tag, (2004) & $\begin{array}{l}\text { Reflects positively on the library } \\
\text { instruction }\end{array}$ & \\
\hline
\end{tabular}

Table 2. Summary of library instruction programs reported in literature 
Library managers should provide a clearer strategy to develop and implement CRM-related activities in order to meet their mission and objectives. Instruction strategies are frontline tools that allow libraries to assist users and maintain relationships with them. Library managers also have to listen to the users so as to improve their customer strategy. Moreover, managers must provide communication channels, through which they can generate user feedback and understand their experiences.

\subsection{Library use}

Libraries today must find ways to optimize operations, minimize resources, enhance services, extend market penetration, and serve customers (Abram, 2007). Prior to the emergence of a digitized environment in the mid-1990, library users were regarded as patrons and library managers emphasized on the collections' development (Osiobe, 1981; Haider, 1996) and book availability (Rashid, 1990) rather than on service provision.

Viewing users as customers was first mentioned by Millson-Martula and Menon (1995). They report that gaps between the library and customers exist, such as the lack of interaction between library staff and the students and faculty. Jerabek et al. (2001) indicate that libraries should develop alternative ways to help users in utilizing their resources. Table 3 presents the anxiety, discontent information, and complaint behaviors reported by users while in the library.

\begin{tabular}{|l|l|l|}
\hline Authors and year & Main findings & Conclusions \\
\hline Onweugbuzie (1997) & Fear of interpersonal with library & Individual instruction \\
\hline Ercegovac (1997) & $\begin{array}{l}\text { Define the transition of today's } \\
\text { libraries as a storage service } \\
\text { provider }\end{array}$ & $\begin{array}{l}\text { Design a user-centered } \\
\text { information access } \\
\text { instructional program }\end{array}$ \\
\hline Jayne and Meer (1997) & $\begin{array}{l}\text { Websites are suitable in } \\
\text { demonstrating instructional } \\
\text { applications }\end{array}$ & $\begin{array}{l}\text { Develop a collaborative } \\
\text { program about the } \\
\text { instructional uses of WWW }\end{array}$ \\
\hline Jiao et al. (1998) & Lack persistence in learning & Provide visual instruction \\
\hline Jerabek et al. (2001) & $\begin{array}{l}\text { Fear of interpersonal contact, } \\
\text { computer, problem solving } \\
\text { strategies }\end{array}$ & $\begin{array}{l}\text { Develop alternative ways of } \\
\text { helping users }\end{array}$ \\
\hline Oh (2004) & Negative attitude & $\begin{array}{l}\text { Loyalty increases when users } \\
\text { have a positive attitude }\end{array}$ \\
\hline Anwar et al. (2004) & $\begin{array}{l}\text { Gender of library user does not } \\
\text { have any significant relationship } \\
\text { with library anxiety }\end{array}$ & $\begin{array}{l}\text { View negative response as } \\
\text { valuable feedback } \\
\text { in library uage of instruction } \\
\text { anxiety }\end{array}$ \\
\hline $\begin{array}{l}\text { Mizrachi and Shoham } \\
\text { (2004) }\end{array}$ & $\begin{array}{l}\text { College library } \\
\text { instruction courses and } \\
\text { workshops should be mandatory } \\
\text { for all students at all levels from } \\
\text { beginner to advanced }\end{array}$ & $\begin{array}{l}\text { Opportunities for informal } \\
\text { and recreational } \\
\text { computer use should also be } \\
\text { provided }\end{array}$ \\
\hline
\end{tabular}

Table 3. Summary of library user feedback as reported in literature 
Providing individual instruction to users is a much needed service by graduate students; this elevates loyalty and ensures a good relationship between the library and users. Given that the needs for resources are different between users, redesigning library resources during the change from physical to electronic mode is also important. In this case, there are still gaps between library user demands and manager suppliers. This issue should be addressed in creating an instructional program.

\section{Service framework}

Peter Drucker defines marketing concepts as "the business as seen from the customer's point of view." Keating and Hafner (2002) state that business models can be applied to libraries; they also draw analogies from business by substituting "library" with "corporation and "user" with "customer." The e-Business domain has been employed extensively in governments, libraries, and diverse non-profit organizations. Constantinides (2002) proposes the Web-Marketing Mix (WMM) model, which can be used to identify the critical online marketing elements and address e-Commerce strategic, operational, organizational, and technical issues using Scope, Site, Synergy, and System (4S).

Scope identifies the strategic and operational objectives to be addressed; Site refers to a method for drafting realistic and consistent Web marketing plans in order to develop the functional platform of communication, interaction, and transaction with the Web-based customers; Synergy refers to the necessary organization, infrastructure, human resource, and knowledge required in supporting smooth online operational processes; and System identifies the main technological and administrative issues that underpin online marketing activities.

\section{$3.14 S$}

Further explanations of each component of $4 S$ are provided in this section to illustrate its implementation into our proposed conceptual framework.

Scope measures the strategic direction that managers should take to ensure that the whole staff follows the organization's predefined goals and objectives. A desire to establish benchmarking across institutions exists by identifying, understanding, and adapting external practices of other organizations in order to measure an organization's internal processes to achieve continuous improvement (Hernon, et al., 1999). To administer user profiles and sustain activities, segmentation of users is helpful in reaching the goal of setting and positioning the strategic role of the library during the service process.

Site evaluates how well a Website complies with the presetting functional requirements. A Libweb opens the collections and services (Hazard, 2003) to users, and is used as a powerful communication channel (Kuchi, 2006). It is also one of the most important communication channels between the library and its users in the digital environment. Through the Libweb, a library distinguishes the behavior and attitude of users while browsing through the sites as well as provides the newest information and recommendations at the same time.

Synergy is applied to all necessary organizational issues, such as back-end support or knowledge capability. The best customers are the loyal ones (Reinartz, and Kumar, 2002). The Internet fosters loyal customers, allowing organizations to develop close relationships with their customers (Jurewicz, and Cutler, 2003). 
System examines whether or not the library uses necessary technologies to support the technical-related services during transactional (e.g., borrowing/returning books) processes.

In order to implement the marketing concept into library service and improve effectiveness and efficiency, this study proposes an integrated service framework for users from a CRM perspective. Fig.2 illustrates the integration between library users and organizations, commencing with a detailed review of the curator's strategy. Each dimension is connected with a plus sign, which represents the correlation and feedback among these dimensions.

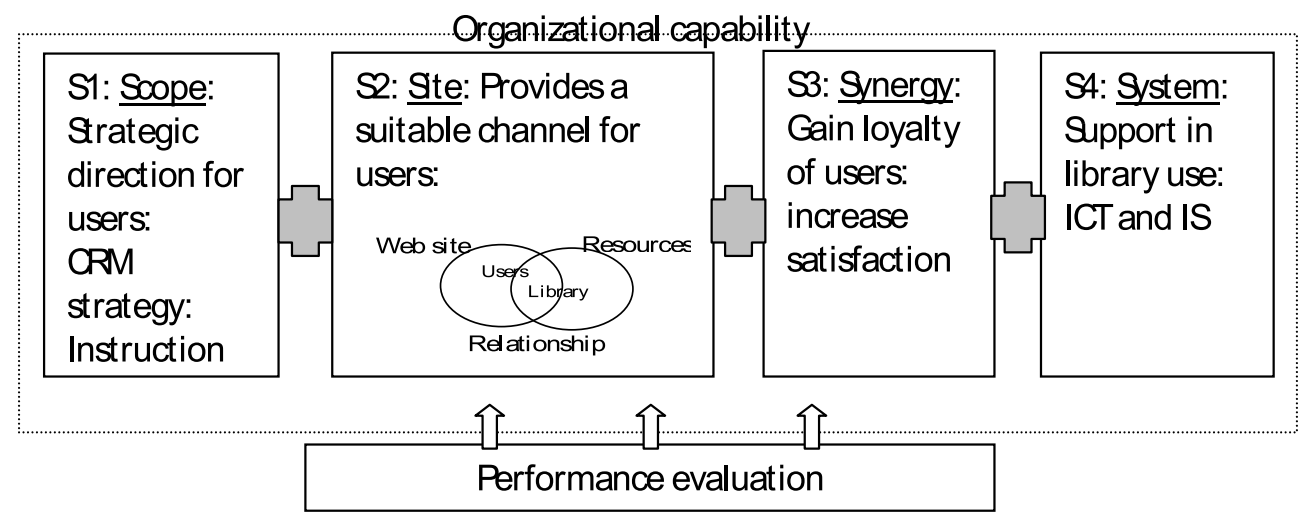

Fig. 2. Service framework for library users

\subsection{S1: Strategic direction for users: CRM strategy: Instruction}

A library must clearly understand its mission and goals to support teaching, research and learning, as well as identify the characteristics of users to provide adequate instructional programs. On the strategic stage, a library manager should create an CRM strategy focusing on the organization and customer instructional programs. Such strategy should provide the library with a clearer platform, with which to develop and implement CRM activities (Payne and Frow, 2005). Most universities have already established their library tour guides for new users; however, lack of advanced instruction for users in the class program still exists. The S1 element is a primarily strategic character, which outlines the decisions to be made in library organziations.

\subsection{S2: Provides a suitable channel for users}

Good communcation strategies are essential for the success of CRM (Broady-Preston, 2006). Users face an increased range of channel options. The effective library-users relationship managing within a multichannel environment requires efficient CRM (Payne and Frow, 2004). Nowadays, a Website is the most useful channel and a direct gateway between the library (which provides information) and the users (the ones who access resources). ICTs offer many tools in establishing the relationship between library and users, including direct mail, telephone services, facsimiles, call centers, and 3G mobile services. In the S2 element, a Website is the library-user interface and the primary source of customer experience data, making it the most important communication element of e-Commerce (Constantinides, 2002). 
Mohammed et al. (2002) provide a 7Cs framework, through which a customer interface design can achieve success. The 7Cs refer to context, content, community, customization, communication, connection, and commerce. Similar to a storefront, a good Website interace provides effective online connections. In addiiton, multichannel integration is an important process in CRM, which gathers and deploys user information and integrates it with other relevant information. This stage stipulates the output of the organizational strategy and value creation into value-added activities with users (Payne and Frow, 2005).

\subsection{S3: Gain loyalty of users: Increase satisfaction}

Synergy is defined as the integrating processes necessary for realizing the virtual ortganzation's objectives; such synergies can develop between the virtual and the physical organization (Constantinides, 2002). Organizations move from product- or brand-centric marketing to a more customer-centric approach, i.e., one-to-one communication capabilities (Reinartz, et al., 2004). Libraries view users as customers and encourage their continued patronage by increasing user satisfaction. Customer satisfaction leads to loyalty and is an important CRM tool in identifying, rewarding, and retain customers (Kumar and Reinartz, 2006). To create a sense of customer loyalty, Amazon.com offers a number of personalization features.

Libraries use ICTs to provide personalized service and generate user satisfaction (Ullen and Germain, 2002). Jeff Barry (2000) notes that advanced ways of leveraging technologies in enhancing library services generally come from library personnel. Customer retention represents a significant part of the value creation (Payne and Frow, 2005). The insights gained from this stage provides guidelines of user satisfaction and ICT; hence, information system (IS) is offered as a tool to link the resources owned or not owned by library.

\subsection{S4: Support in library use: ICT and IS}

In e-Commerce, System refers to technological capabilities and is widely considered as the main driving force behind the Internet growth (Constantinides, 2002). ICTs and IS are considered as bases that support CRM activities. ICT remains as the functional backbone of e-Commerce activities and entails the following system-related decisions (Constantinides, 2002):

- Website administration, maintenance and service;

- Web server hosting and choice of the Internet service provider;

- Site construction;

- Content management;

- $\quad$ Site security;

- Transaction functionality;

- Collection; and

- System backup.

ICT supports many activities involved in directly interfacing with customers and managing internal operations, administration, and supplier relaitonships (Greenberg, 2001). In the S4 stage, the organizational capacity to scale existing systems or plan for the migration to larger systems without disrupting business operations is critical. The information management 
process considers the collection, collation, and use of customer data from all customer contact points in order to generate customer insight and the appropriate marketing responses (Payne and Frow, 2005). Table 3.1 defines the $4 S$ marketing concept applied in library organization.

Using the service framework from the CRM perspective proposed in this study, the work process becoms smoother and quicker in each stage. In this system, resources are provided on-site or from remote storage locations (i.e., online or hard copy) based on the needs of the users and the objectives of the organization (Lakshmi, 2003). This integrated service framework demonstrates the interative arrangement of services that commences a strategic direction.

\section{Method}

Average scores do not exactly define performance evaluation due to the different degrees of standardization. Generally, two indicators are applied on service elements to evaluate the corresponding service quality performance, namely, importance (potential performance or PP) and satisfaction (actual performance or AP) (Hung, et al., 2003). Service quality refers to the degree of an event or experience, which meets individual needs or expectations. Customers are overwhelmed with service quality when customer perception (AP) exceeds customer expectation (PP) (AP>PP). Meanwhile, customers are moderately satisfied when customer perception (AP) is approximately equal to customer expectation ( $\mathrm{PP})(\mathrm{AP}=\mathrm{PP})$. The worse situation is when customers are dissatisfied, in which customers perception (AP) is below customer expectation (PP), resulting in satisfaction which is below expectation $(\mathrm{AP}<\mathrm{PP})$. Thus, managers are obliged to improve and enhance service quality to satisfy and retain customers (Hung et al., 2003).

\subsection{Performance evaluation}

The performance evaluation matrix (Lambert \& Sharma, 1990; Lambert \& Stock, 1999) measures customer satisfaction and expectation on each service element to provide managers with the service quality information and prioritize improvement plans for service elements that gained dissatisfied response from customers. The results of performance evaluation and customer importance are jointly determined by the location in the matrix. This location is used to evaluate service quality performance, as shown in Figure 3.

In Fig.3, the performance evaluation of customer importance is plotted against the $\mathrm{X}$-axis (AP) and Y-axis (PP). The resulting formulation derives a score of mean and standard deviation (SD). The gap analysis depends on the actual performance compared with potential performance as well as on the viewpoint of curators regarding library service enhancement and promotions.

Library managers can identify and understand user preferences with regards the actual performance of library services through the help of ICTs and IS. However, empirical work in gap analysis shows that user preferences clearly depend on the disparity between actual performance and potential performance. To resolve this apparent discrepancy between AP and PP, the present study shows that a simple reinterpretation of services from the CRM perspective fills the gap between the two performances. This study interprets AP as the 
current service provided and PP as user service expectations from the curator's viewpoint. Here, $\mathrm{AP}<\mathrm{PP}$ indicates poor service and dissatisfied users; $\mathrm{AP}=\mathrm{PP}$ indicates normal service and no need for specific impressions; and $\mathrm{AP}>\mathrm{PP}$ indicates good service and satisfied users.

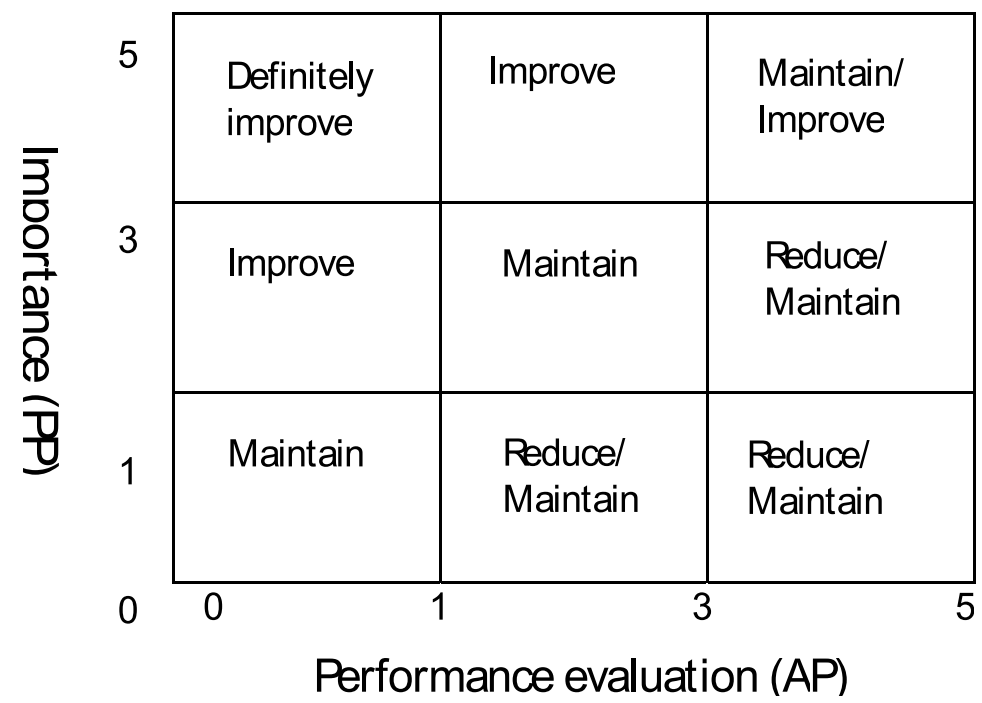

Fig. 3. Performance evaluation matrix

According to satisfaction theory, individuals are satisfied when expectations are met (Oliver, 1980, 1997; Tan and Sutherland, 2004). Statistically, this premise is expressed as: $\sum\left(D_{i}-V\right)$, where $\mathrm{D}$ is the value of AP, $i$ is the value of the item, and $V$ is the value of PP. A gap is simply an expert's perception service of AP (D) minus the value of the PP (V) of factors (D$\mathrm{V})$. In this framework, an increasing gap score in each type tends to increase its user dissatisfaction if the performance is below PP and decrease if performance is above PP. Increasing user satisfaction is the core strategy of libraries.

\subsection{Participants}

The goal of the sample selection is to find comparable libraries. In the present work, we decided to include only ten public Technical and Vocational Education System (TVES) libraries of Taiwan and not other types of university libraries. These libraries offered resources to students come from another educational system other than the traditional one. In their technical and vocational senior high school years, they receive hands-on training that prepares them to be practitioners rather than theorists, and much more importance is placed on the practical than the abstract in their training. Yet nearly every one of them now receives higher education in a certain academic discipline in institutes of higher education (IHEs) and is expected to achieve college level upon entrance (Wen, 2008).

Questionnaires were mailed to 10 managers serving as the curators of TVES universities in Taiwan. All questionnaires were sent via first class mail in early May, 2009, and eight were 
returned at the end of the month. Such universities were chosen because of their public status and because they had similar budget allocations, evaluation criteria, organizational cultures, and standard processes. Moreover, student backgrounds were also the same among these universities.

Managers relate to the awareness of services and resources provided, use of services and resources offered from a user-centered perspective. Questions were formulated to ascertain the perceptions, expectations, and general information needs of the library services. The survey was conducted with efficient and effective data entry and analysis.

\section{Results}

$\mathrm{AP}$ and PP results in each level are presented in this section. The entire mean of AP is lower than PP. Table 4-7 lists each dimension of mean and SD.

The factors "Make the classroom more interactive by implementing one-on-one instruction" and "The effect of library instruction will lead to user satisfaction" show a very low mean score of 3.0000 for AP. The cooperation of the library and faculty is important for implementing instructional programs (Table 4).

\begin{tabular}{|l|c|c|c|c|}
\hline \multirow{2}{*}{$\begin{array}{c}\text { Factors } \\
\text { (S1: Strategic direction for users: CRM } \\
\text { strategy: Instruction) }\end{array}$} & \multicolumn{2}{c|}{ PP } & \multicolumn{2}{c|}{ AP } \\
\cline { 2 - 5 } & Mean & SD & Mean & SD \\
\hline $\begin{array}{l}\text { 1. Libraries must establish programs in } \\
\text { collaboration with teaching faculty in the class }\end{array}$ & 4.1250 & .6409 & 3.3750 & .5175 \\
\hline $\begin{array}{l}\text { 2. Make classrooms more interactive with } \\
\text { one-on-one instruction }\end{array}$ & 3.5000 & 1.3093 & 3.0000 & 1.1952 \\
\hline $\begin{array}{l}\text { 3. Information search is increasing after the } \\
\text { instruction training }\end{array}$ & 4.0000 & .7559 & 4.0000 & .7559 \\
\hline $\begin{array}{l}\text { 4. The effect of library instruction lead to user } \\
\text { satisfaction }\end{array}$ & 3.7500 & .4629 & 3.0000 & .5345 \\
\hline $\begin{array}{l}\text { 5. Enhance Web-based instruction } \\
\text { 6. Design valid assessment programs and } \\
\text { accurate documentation of student learning }\end{array}$ & 4.3750 & .7440 & 3.1250 & .8345 \\
\hline & \multicolumn{1}{|c|}{$\mathrm{Mp}=3.9792$} & .6409 & 3.3750 & 1.1877 \\
\hline
\end{tabular}

Table 4. Mean and SD of "Strategic direction for users: CRM strategy: Instruction"

"High-quality Internet information" and "Designers need better guidelines in building public access interfaces" obtain the highest mean score of 5.0000 for PP. The differences between AP and PP in this level are the lowest, indicating that the library is aware of the importance of building relationship with the users (Table 5). 


\begin{tabular}{|l|c|c|c|c|}
\hline \multirow{2}{*}{$\begin{array}{c}\text { Factors } \\
\text { (S2: Provide a suitable channel with users) }\end{array}$} & \multicolumn{2}{|c|}{ PP } & \multicolumn{2}{c|}{ AP } \\
\cline { 2 - 5 } $\begin{array}{l}\text { 1. Meet the goals and mission statement of } \\
\text { the library }\end{array}$ & 4.5000 & .7559 & 3.8750 & .6409 \\
\hline $\begin{array}{l}\text { 2. Integrating library service in both printed } \\
\text { and electronic resources }\end{array}$ & 4.8750 & .3536 & 4.1250 & .9910 \\
\hline 3. Ease of use & 4.8750 & .3536 & 4.1250 & 1.1260 \\
\hline $\begin{array}{l}\text { 4. Design a pleasing interface and easy to } \\
\text { use Website }\end{array}$ & 4.2500 & .7071 & 4.0000 & 1.1952 \\
\hline 5. Create a more intuitive Web interface & 4.7500 & .4629 & 4.0000 & 1.0690 \\
\hline 6. High-quality Internet information & 5.0000 & .0000 & 4.1250 & .8345 \\
\hline $\begin{array}{l}\text { 7. Designers need better guideline on } \\
\text { building public access interfaces }\end{array}$ & 5.0000 & .0000 & 3.8750 & 1.1260 \\
\hline & \multicolumn{2}{|c|}{$\mathrm{Md}=4.7500$} & \multicolumn{3}{c|}{$\mathrm{Mp}=4.0179$} \\
\hline
\end{tabular}

Table 5. Mean and SD of "Provides a suitable channel for users"

Three factors resulted in a mean score of 5.0000. These include "Plan strategy that integrate digital and print collections," "Well-developed library management method," and "Develop identified user care strategies: technology, utility, and call centers." Although user satisfaction is often explored, meeting user needs and expectation is not enough; hence, these should always be the top priority of service providers (Table 6).

\begin{tabular}{|c|c|c|c|c|}
\hline \multirow{2}{*}{$\begin{array}{c}\text { Factors } \\
\text { (S3: Gain loyalty of users) }\end{array}$} & \multicolumn{2}{|c|}{ PP } & \multicolumn{2}{|c|}{$\mathrm{AP}$} \\
\hline & Mean & SD & Mean & SD \\
\hline $\begin{array}{l}\text { 1. Plan strategies that integrate digital and } \\
\text { print collections }\end{array}$ & 5.0000 & .0000 & 4.0000 & 1.1952 \\
\hline $\begin{array}{l}\text { 2. Listen to the users and encourage staff } \\
\text { involvement into organizational structure }\end{array}$ & 4.2500 & .8864 & 3.6250 & .5175 \\
\hline 3. Establish benchmarking & 4.0000 & .5345 & 3.1250 & 6409 \\
\hline $\begin{array}{l}\text { 4. Develop the strategy of one-to-one } \\
\text { relationship management }\end{array}$ & 3.7500 & .8864 & 2.7500 & .8864 \\
\hline $\begin{array}{l}\text { 5. Friendly, helpful, and professional } \\
\text { guidance }\end{array}$ & 4.7500 & .4629 & 4.1250 & 1.3562 \\
\hline $\begin{array}{l}\text { 6. Well-developed library management } \\
\text { method }\end{array}$ & 5.0000 & .0000 & 4.0000 & 1.1952 \\
\hline \multirow[t]{2}{*}{$\begin{array}{l}\text { 7. Develop identified user care strategies, } \\
\text { such as technology, utility, and call centers }\end{array}$} & 5.0000 & .0000 & 4.1250 & .8345 \\
\hline & \multicolumn{2}{|c|}{$\mathrm{Md}=4.482$} & \multicolumn{2}{|c|}{$\mathrm{Mp}=3.6786$} \\
\hline
\end{tabular}

Table 6. Mean and SD of "Gain loyalty of users: increase satisfaction"

The mean in this level is the lowest among all factors. The mean in AP indicates three factors, including "Instruct individually," "Designing user-centered information access instructional programs," and "Develop a collaborative program about the instructional uses of WWW," all of which show a score of less than 3. Such factors are perceived to be "not met" by the participants (Table 7). 


\begin{tabular}{|c|c|c|c|c|}
\hline \multirow{2}{*}{$\begin{array}{c}\text { Factors } \\
\text { (S4: Support in library use of users: } \\
\text { ICT, IS) }\end{array}$} & \multicolumn{2}{|c|}{ PP } & \multicolumn{2}{|c|}{$\mathrm{AP}$} \\
\hline & Mean & SD & Mean & SD \\
\hline 1. Instruct individually & 3.1250 & .8345 & 2.6250 & 1.0607 \\
\hline $\begin{array}{l}\text { 2. Designing user-centered information } \\
\text { access instructional programs }\end{array}$ & 4.0000 & 1.0690 & 2.7500 & 1.0351 \\
\hline $\begin{array}{l}\text { 3. Develop a collaborative program about } \\
\text { the instructional uses of WWW }\end{array}$ & 3.6250 & .9161 & 2.7500 & 1.0351 \\
\hline 4. Provide visual instruction & 3.2500 & 1.1650 & 2.8750 & 1.1260 \\
\hline 5. Develop alternative ways of helping users & 3.6250 & .9161 & 3.0000 & 1.0690 \\
\hline $\begin{array}{l}\text { 6. Reuse up while users are in a positive } \\
\text { attitude }\end{array}$ & 4.1250 & .6409 & 4.2500 & 1.1650 \\
\hline \multirow[t]{2}{*}{$\begin{array}{l}\text { 7. View negative response as valuable } \\
\text { feedback }\end{array}$} & 3.7500 & .7071 & 3.7500 & 1.2817 \\
\hline & \multicolumn{2}{|c|}{$\mathrm{Md}=3.7981$} & \multicolumn{2}{|c|}{$\mathrm{Mp}=3.2212$} \\
\hline
\end{tabular}

Table 7. Mean and SD of "Support in library use of users: ICT and IS"

A closer examination of the data reveals that the largest negative gap scores (-1.125) are obtained for "Designers need better guideline on building public access interfaces." This demonstrates the effect of ICTs on the development of library service. Second, the gap score of "Design valid assessment programs and accurate documentation of student learning" and "Design user-centered information access instructional programs" is -1.25 , which means that user-center service should be considered.

Meanwhile, "High-quality Internet information" and "Designers need better guidelines in building public access interfaces" have a mean score of 5.000 in the PP. Thus, ICT settings and related facilities in libraries should be accessible and support the satisfaction of user needs.

As for "Develop identified user care strategies: technology, utility, and call centers" and "Plan strategy that integrate digital and print collections," these have a mean score of 5.0000 in the potential score. Hence, CRM strategy to meet user satisfaction should be considered carefully, especially the integration of electronic and printed resources. Figure 4 plots each factor in the dimensions of AP and PP values. It also shows the performance evaluation matrix diagram.

Fig.4 llustrates a diagonal line dividing the square into two parts. As can be seen, most of the dots are located in the top-right (maintain/improve cell), indicating that the importance of these levels are high. Three dots are located on the left of diagonal line, indicating that the service in this area should be maintained. Efforts must be exerted so that the dots located in the right of diagonal line showed that the service in this area should be improved. 


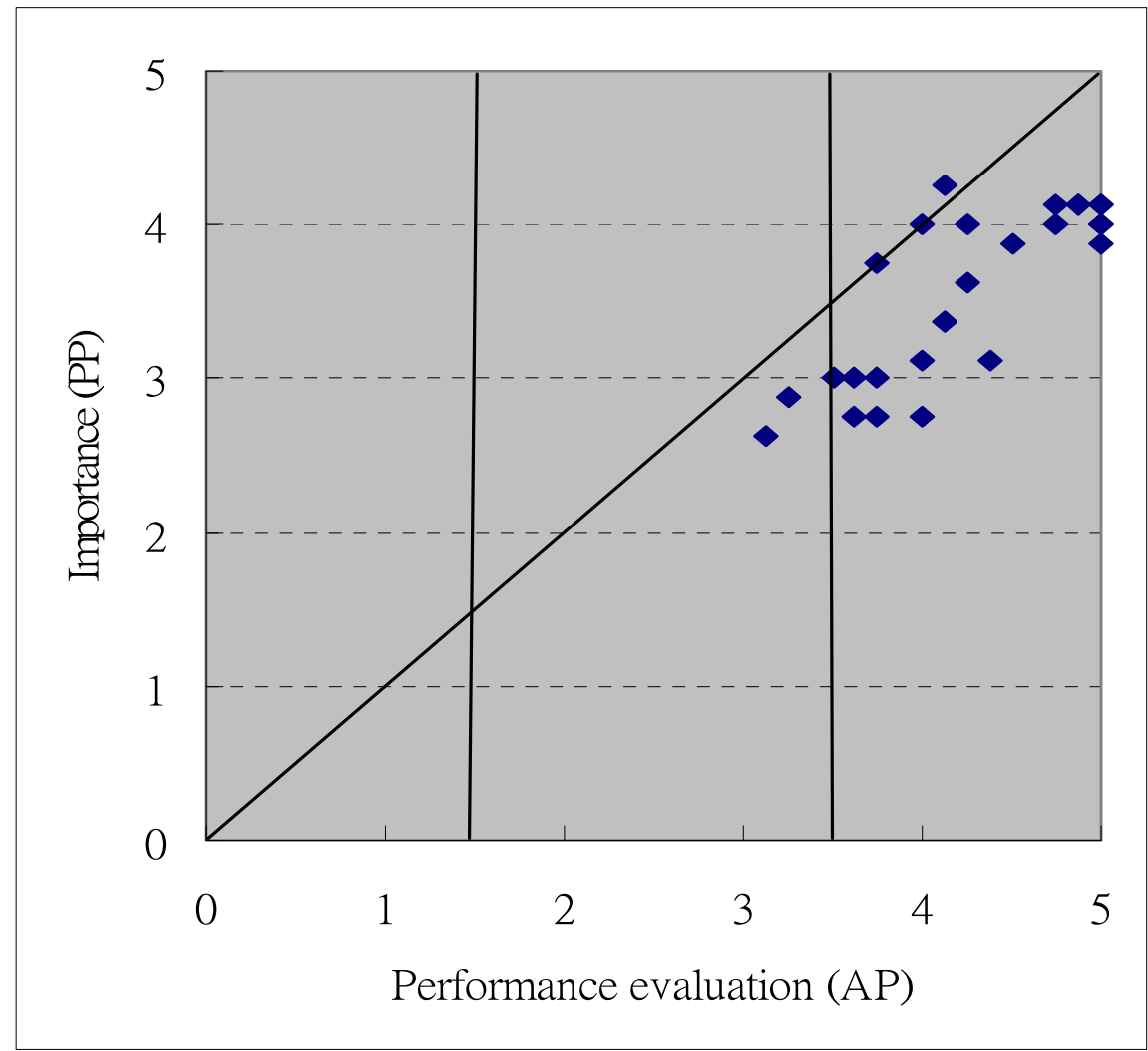

Fig. 4. The performance matrix of AP and PP values

\section{Conclusion}

Libraries often face budget deficiency and reduced resources under the operation and management style of non-profit organizations. Since their goal is to be a service organization, they must continually think of ways and strategies to attract users to utilize their resources. CRM is not a tactical or functional approach, but is a key strategic process that can achieve such a goal. A comprehensive CRM highlights the preferences and learning needs of users focused on cost-efficiency as well as enhances customer retention and loyalty. This study proposes an integrated conceptual model through a business-marketing plan and CRM perspective using literature findings, expert interviews, and a survey of library experts for the verification of the model in practice.

The present study successfully introduces the concept of the CRM perspective to the field of library and information science. The significant concepts generated from this perspective include a marketing approach intended to improve library effectiveness, instructions for increasing user satisfaction. Such notions have only been utilized in the field of business administration, but not in the target field. Thus, in our approach, wr viewed library users as "customers" who seek satisfaction from the marketplace, i.e., "library." 
More significantly, the present can be regarded as one of the few leading studies in the field, which investigates the effects of a managerial viewpoint in library services. Finally, this study can be viewed as a call for decision-makers to give more attention to university students in receiving higher education.

The proliferation of the Internet and ICTS has transformed the ways by which information is created, disseminated, stored, and accessed. Libraries must harness and utilize recent technological developments to fulfill their mission of providing access to information to meet the students' needs. Indeed, students are customers, and the libraries must establish interaction with them to identify their needs and difficulties in using library resources. "Library instruction" should not be ignored in the digital environment and ICT emergence. On the contrary, research on the instruction issues in an active and interactive way has progressed. Olson (2000), for example, addresses one-on-one instruction to promote the students' self-confidence and encourage them to freely assess and evaluate the resources of information. Keating and Hafner (2002) invite individual customers to think actively about the applicability of business concepts to academic library services. They then propose a model, which is applied for one-to-one library service.

University students include freshmen, sophomores, juniors, and seniors. A barrier certainly exists to overcome the manipulation of one-to-one relationship model for each of them. Sinn (1998) and Silver and Nickel (2007) offer library instructions to psychology and biology students and find that the instructions should be made according to characteristics of the students. Researchers focused on a composite class, in which students come from different colleges, encourage them to discuss in class their perspectives after using the library resources, thus enhancing their information literacy from this course.

\section{Appendix A}

Please tick the number from (1) to (5), ranging from extremely important (5) to not important at all (1) into the $\square$. In your own viewpoint, rate how important you believe each university library service is. Do not think about your current university; instead, think about your expectations of the quality of services in a typical university library.

\begin{tabular}{|c|c|c|c|c|}
\hline \multicolumn{5}{|c|}{$\begin{array}{l}\text { (A) You think your } \\
\text { library should } \\
\text { provide such service. }\end{array}$} \\
\hline \multicolumn{5}{|c|}{$\downarrow$} \\
\hline 1 & & 3 & & 5 \\
\hline$\square$ & $\square$ & $\square$ & $\square$ & $\square$ \\
\hline$\square$ & $\square$ & $\square$ & $\square$ & $\square$ \\
\hline$\square$ & $\square$ & $\square$ & $\square$ & $\square$ \\
\hline$\square$ & $\square$ & $\square$ & $\square$ & $\square$ \\
\hline$\square$ & $\square$ & $\square$ & $\square$ & $\square$ \\
\hline 口 & 口 & $\square$ & 口 & $\square$ \\
\hline
\end{tabular}

1. Libraries establish programs in collaboration with teaching faculty in the class

2. Make classrooms more interactive with one-on-one instruction

3. Information search is increasing after the instruction training

4. The effect of library instruction leads to user satisfaction

5. Enhance Web-based instruction

6. Design valid assessment programs and accurate documentation of student learning

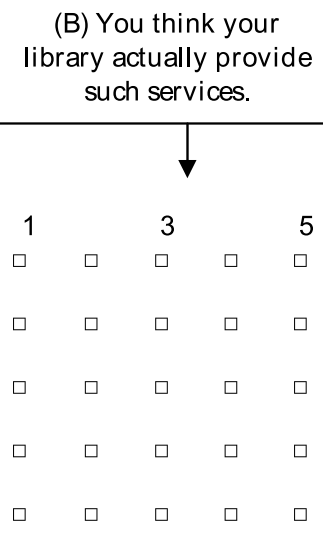

(B) You think your

such services.

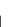

$\square$

$\square$

$\square$ 
Phase 2 : Provides a suitable channel for users

$\begin{array}{lllll}1 & & 3 & & 5 \\ \square & \square & \square & \square & \square \\ \square & \square & \square & \square & \square \\ \square & \square & \square & \square & \square \\ \square & \square & \square & \square & \square \\ \square & \square & \square & \square & \square \\ \square & \square & \square & \square & \square \\ \square & \square & \square & \square & \square\end{array}$

1. Meet the goals and mission statement of the library

2. Integrating library service in both printed and electronic resources

3. Ease of use

4. Design a pleasing interface and easy to use Website

5. Oreate a more intuitive web interface

6. High-quality Internet information

7. Designers need better guidelines in building public access interfaces

Phase 3 : Reenter to use the library (Increase satisfaction)

$\begin{array}{ccccc}1 & & 3 & & 5 \\ \square & \square & \square & \square & \square \\ \square & \square & \square & \square & \square \\ \square & \square & \square & \square & \square \\ \square & \square & \square & \square & \square \\ \square & \square & \square & \square & \square \\ \square & \square & \square & \square & \square \\ \square & \square & \square & \square & \square\end{array}$

1. Plan strategies that integrate digital and print collections

2. Listen to the users and encourage staff involvement in the organizational structure

3. Establish benchmarking

4. Develop the strategy of one-to-one relationship management

5. Friendly, helpful, and professional guidance

6 . Well-developed library management method

7. Develop identified user care strategies, such as technology, utility, and call centers

Phase 4 : Support for use: ICT and IS

$\begin{array}{lllll}1 & & 3 & & 5 \\ \square & \square & \square & \square & \square \\ \square & \square & \square & \square & \square \\ \square & \square & \square & \square & \square \\ \square & \square & \square & \square & \square \\ \square & \square & \square & \square & \square \\ \square & \square & \square & \square & \square \\ \square & \square & \square & \square & \square\end{array}$
1. Instruct individually
2. Designing user-centered information access instructional programs
3. Develop a collaborative program about the instructional use of $\mathrm{WWW}$
4. Provide visual instruction
5. Develop alternative ways of helping users
6. Reuse up while users are in a positive attitude
7. View negative response as valuable feedback

\section{References}

Abram, S. (2007). The value of libraries: impact, normative data, \& influencing funders, Cirsi OneSource, 2(5).

Anwar, M. A., Al-Kandari, N. M., and Al-Qallaf, C. L. (2004), Use of Bostick's library anxiety scale on undergraduate biological sciences students of Kuwait university, Library \& Information Science Research,26 (2004),pp.266-283.

Bex, Jane and Miller, Anna, (1999), Users' views on UK academic networked information services, Education for Informaiton, 17, pp.145-154. 
Bielema, Cheryl, Crocker, Dan, Miller, Joan, Reynolds-Moehrle, Jennifer, and Shaw, Helen, (2007), Faculty and librarian collaborations: A case study and proposal for online learning environments, Research Strategies, Vol.20, No.4, pp.334-345.

Borchert, C. A. (2006), Untangling the jungle of e-journal access issues using CRM software, Library Collections, Acquisitions, and Technical Services, 30(3-4), pp.224-237.

Broady-Preston, Felice, Joanna, and Marshall, Susan, (2006), Building better customer relationships: case studies from Malta and the UK, Library Management, 27(6/7), pp.430-445.

Cardwell, C., Furlong, K., and O'Keeffe, J. (2001), My librarian: Personalized research clinics and the academic library, Research Strategies, 18(2), pp.97-111.

Chen, T. S., Lin, M. H., and Wu, C. H. (2004), Enhancing library resources usage efficiency by data mining, Proceedings of the IEEE International Conference on Networking, Sensing \& Control, pp.382-387.

Chu, Pi. Ching, (2005), A study of library acquisition and cataloging from the viewpoint of customer relationship management, Central University Library Journal, Taoyuan: Jhongli.

Constantinides, E. (2002), The 4S Web-Marketing Mix model, Electronic Commerce Research and Applications, pp. 57-76.

Cooper, R., Dempsey P.R. (1998), Remote library users-needs and expectations, Library Trends, 47(1), pp.42-65.

Cullen, R. (2001), Perspectives on users satisfaction surveys, Library Trends, 49(4), pp.662686.

Dlamini, Petros N. (2006), Customer care services and strategies in academic libraries in KwaZulu-Natal, Journal of Library \& Information Science, 72(2), pp.119-130.

Drucker, Peter, (1973), Management: Tasks, Responsibilities, Practices. Harper and Row, New York.

Ercegovac, Zorana, (1997), The interpretations of library use in the age of digital libraries: Virtualizing the name, Library \& Information Science Research, 19(1), pp. 35-51.

Fan, Weiguo, Gordon, Michael D. and Pathak, Praveen, (2005), Effective profiling of consumer information retrieval needs: a unified framework and empirical comparison, Decision Support Systems, Vol.40, No.2, pp.213-233.

Flanagan, P. and Horowitz, R. (2000), Exploring new service models: can consolidating public service points improve response to customer needs? Journal of Academic Librarianship, 26(5), pp.329-338.

Frias-Martinez, E. Magoulas, G., Chen, S. and Macredie, R., (2006), Automated user modeling for personalized digital libraries, International Journal of Information Management, Vol.26, No.3, pp.234-248.

Giacomo, Mariella Di \& Knudson, 2004, MyLibrary @LANL, a Personalized and Collaborative Digital Library Portal for Facilitating Scientific Research, Los Alamos National Laboratory Research Library.

Green, Andrew, (1990), What do we mean by user needs? British Journal of Academic Librarianship. 5(2), pp.65-78.

Haider, Syed Jalaluddin, (1996), Acquisitions and collections development in Pakistan, Library Acquisitions: Practice \& Theory, 20(2), pp.147-156.

Hazard, B. (2003), Online fundraising at ARL libraries, The Journal of Academic Librarianship, 29(1), pp.8-15. 
Heckart, Ronald J. (1999), Imagining the digital library in a commercialized internet, The Journal of Academic Librarianship, 25(4), pp.274-280.

Hernon, Peter and Altman, Ellen, (1998), Assessing service quality: satisfying the expectations of library customers, Chicago: American Library Association.

Hernon, Peter and Calvert, Philip, (2005), E-service quality in libraries: exploring its features and dimensions, Library \& Information Science Research, Vol. 27, pp.377-404

Hernon, Peter, Nitecki, Danuta A., and Altman, Ellen, (1999), Service quality and customer satisfaction: An assessment and future directions, The Journal of Academic Librarianship, Vol.25, No.1, pp.9-17.

Hicks, David, (2003), Supporting personalization and customization in a collaborative setting, Computers in Industry, Vol.52, No.1, pp.71-79.

Hinchliffe, J. (2000), Faculty-directed library use instruction: A single class, retrospective study, Research Strategies, 17(4), pp.281-289.

Huang, R. (2007), Study and analysis of information on the reader's potential discontent in an academic library, Library Management, 28(1/2), pp.27-35.

Hung, Y.H., Huang, M. L., and Chen, K. S., (2003), Service quality evaluation by service quality performance matrix, Total Quality Management, Vol. 14, No.1, pp.79-89.

Jayne, Elaine, and Meer, Vander, (1997), The library's role in academic instructional use of the World Wide Web, Research Strategies, 15(3), pp.123-150.

Jerabek, J. N., Meyer, L. S., and Kordinak, T. (2001), "Library anxiety" and "computer anxiety:" Measures, validity, and research implications, Library \& Information Science Research, 23(3), pp.277-289.

Jiao, Q. G., Onwuegbuzie, A. J., and Lichtenstein, A.. (1996). Library anxiety: Characteristics of at-risk college students. Library \& Information Science Research, 18, 151- 163.

Jiao, Q. G. and Onwuegbuzie, A. J. (1998), Perfectionism and library anxiety among graduate students, The Journal of Academic Librarianship, 24(5), pp.365-371.

Johnson, Peggy, and MacEwan, Bonnie, (1999), Virtually Yours: Models for Managing Electronic Resources and Services. Chicago: American Library Association.

Julien, Heidi, and Boon, Stuart, (2004), Assessing instructional outcomes in Canadian academic libraries, Library \& Information Science Research, 26(2), pp.121-139.

Jurewicz, Lynn, and Cutler, Todd, (2003), High Tech, High Touch: Library Customer Service Through Technology, Chicago: American Library Association, p.7. [e-Book].

Kao, S. C. Chang, H. C. and Lin, C. H. (2003), Decision support for the academic library acquisition budget allocation via circulation database mining, Information Processing and Management, 39(1), pp.133-147.

Keating, III, John J. and Hafner, Arthur W. (2002), Perspective on ...Supporting individual library patrons with information technologies: emerging one-to-one library services on the college or university campus, The Journal of Academic Librarianship, Vol.38, No.6, pp.426-429.

Keng, K. A., Kwon, J., and Wirtz, J. (2003), Segmentation of library visitors in Singapore, Learning and reading related lifestyles, Library Management, 24(1/2), pp.20-33.

Koohang, Alex and Ondracek, James, (2005), Users' views about the usability of digital libraries, British Journal of Educational Technology, 36(3), pp.407-423.

Kuchi, T. (2006), Communicating mission: an analysis of academic library Web sites, The Journal of Academic Librarianship, 32(2), pp.148-154. 
Kumar, V. and Reinartz, Werner J., (2006), Customer Relationship Management: a databased approach, N.J.: John Wiley \& Sons.

Lambert, D.M. and Sharma, A. (1990), A customer-based competitive analysis for logistics decisions, International Journal of Physical Distribution and Logistics Management, 20, p.23.

Lambert, D.M. and Sharma, A. (1999), Strategic Logistics Management, (Irwin).

Lapidus, Mariana, (2003), Library services for pharmacy and health sciences students: results of a survey, The Journal of Academic Librarianship, 29(4), pp. 237-244.

Lawson, M. D. (2000), Reaching the masses: marketing a library instruction course to incoming freshmen, Research Strategies, 17(1), pp.45-49.

Martensen, Anne and Gronholdt, Lars, (2003), Improving library users' perceived quality, satisfaction and loyalty: an integrated measurement and management system, Journal of Academic librarianship, 29(3), pp.140-147.

Millson-Martula, Christopher and Menon, Vanaja, (1995), Customer Expectations: Concepts and Reality for Academic Library Services. College \& Research Libraries, Vol.56, No.1, pp.33-47.

Mizrachi, D. and Shoham, S. (2004), Computer attitudes and library anxiety among undergraduates: a study of Israeli B.Ed students, The International Information \& Library Review, 36(1), pp.29-38.

Mohammed, R. F., Rpbert, J., Jaworski, J., and Cahill, A. M. (2002), Internet Marketing: Building Advantage in the Networked Economy, Boston: McGraw-Hill/Irwin, p.623.

Nitecki, D. A. (1996), Changing the concept and measure of service quality in academic libraries, The Journal of Academic Librarianship, pp.181-190.

Oh, D. G. (2003), Complaining behavior of public library users in South Korea, Library \& Information Science Research, 25(1), pp.43-62.

Oh, Dong-Geun, (2004), Complaining behavior of academic library users in South Korea, The Journal of Acadecmi Librarianship, 30(2), pp.136-144.

Ojala, M. (1986), Views on end-user searching, The American Society for information Science, 37(4), pp.197-203.

Oliver, Richard L., (1997), Satisfaction: A Behavioral Perspective on the Consumer. New York: McGraw-Hill.

Oliver, Richard L., (1980), "A Cognitive Model of the Antecedents and Consequences of Satisfaction Decisions," Journal of Marketing Research, 17 (November), 460-9.

Olson, John A. (2000), How to encourage students in a library instruction session to use critical and creative-thinking skills: a pilot study, Research Strategies, 16(4), pp.309-314.

Onwuegbuzie, A. J. (1997), Writing a research proposal: the role of library anxiety, statistics anxiety, and composition anxiety, Library \& Information Science Research, 19(1), pp.5-33.

Osiobe, S. A., 1981, The Faculty versus librarians in the acquisitions process: a comparative analysis, Library Acquisitions: Practice \& Theory, 5, pp.9-13.

Payne,A, and Frow, P. (2005), "A strategic framework for customer relationship management", Journal of Marketing", 69 (4), pp.167-176.

Phipps, Shelley, (2001), Beyond measuring service quality: learning from the voices of the customers, the staff, the processes, and the organization, Library Trends, 49(4), pp.635-661. 
Portmann, Chris A. and Roush, Adrienne Julius (2004), Assessing the Effects of Library Instruction, The Journal of Academic Librarianship, 30(6), pp. 461-465.

Ragains, P. (2001), A primer on developing and using course-related library Web pages, Research Strategies, 18(1), pp.85-93.

Rashid, Haseeb F., (1990), Book availability as a performance measure of a library: an analysis of the effectiveness of a health sciences library, Journal of the American Society for Information Science, 41(7), pp.501-507.

Raza, M. Masoom and Nath, Amar, (2007), Use of IT in university libraries of Punjab, Chandigarh and Himachal Pradesh: a comparative study, The International Information \& Library Review, 39(3-4), pp.211-227.

Reinartz, Werner, and Kumar V. (2002), The Mismanagement of customer loyalty, Harvard Business Review, pp.86-94.

Ren, Wen-Hua, (2000), Library instruction and college student self-efficacy in electronic information searching, The Journal of Academic Librarianship, 26(5), pp.323-328.

Renda, M. Elena and Straccia, Umberto, (2005), A personalized collaborative Digital Library environment: a model and an application, Information Processing \& Management, Vol41, No.1, pp.5-21.

Sanborn, L. "Improving library instruction: faculty collaboration", The Journal of Academic Librarianship, 31(5), 2005, pp.477-481.

Shi, X, Holahan, P. J., and Jurkat, M. P. (2004), Satisfaction formation processes in library users: understanding multisource effects, The Journal of Academic Librarianship, 30(2), pp.123-131.

Sinn, R. N. (1998), Library instruction for biology courses: a literature review and survey, Research Strategies, 16(2), pp. 103-115.

Sinn, R. N. (2000), A comparison of library instruction content by biology faculty and librarians, Research Strategies, 17(1), pp.23-34.

Silver, S.L. and Nickel, L.T. "Are online tutorials effective? A comparison of online and classroom library instruction methods," Research Strategies, vol.20, pp.389-396, 2007.

Sykes, Jean, (2007), Improving the student experience-how can the library help?, New Review of Information Networking, Vol.13, No.1, pp.23 - 30.

Tag, Sylvia G. (2004), A Library Instruction Survey for Transfer Students: Implications for Library Services, The Journal of Academic Librarianship, 30(2), pp. 102-108.

Tan, F. B. and Sutherland, P. (2004). Online Consumer Trust: A Multi-Dimensional Model. Journal of Electronic in Organizations, 2(3):40-58.

Van Groenendaal, Willem J.H. (1997), A user's view on the electronic library, Library Acquisitions: Practice \& Theory Vol.21, Issue 3, pp.337-345.

Vander Meer, (2000), Pushing the limits: creative web use in libraries related to instruction, Research Strategies, 17(4), pp.237-256.

Wang, Mei, Yu, (2006), CRM and Library Reader Service, Taipei: Showwe.

Webster, L., and Rielly, L. (2003), A library instruction case study: measuring success from multiple perspectives, Research Strategies,19(1), pp. 16-32.

Wells, John D., Fuerst, William, and Choobineh, Joobin, (1999), Managing information technology (IT) for one-to-one customer interaction, Information \& Management, 35 (53-62). 
Wen, Yvonne Ying-Ya, Wang, Shiow-Luan, and Thomson, Gavin, (2008), Enhancing Cultural Literacy through E-Learning: A Case Study in the TVES of Taiwan, The 2008 International Joint Conference on e-Commerce, e-Administration, e-Society, and e-Education (e-CASE 2008), March 27-29, Bangkok, Thailand. (ISBN 978-98683038-2-9).

Will, Nicole, (2006), Data-mining: Improvement of university library services, Technological Forecasting and Social Change, Vol.73, No.8, pp.1045-1050.

$\mathrm{Wu}$, Shuling, (2007), Investigation and analysis of current use of electronic resources in university libraries, Library Management, 28(1/2), pp.72-88.

Xie, Hong, (2006), Evaluation of digital libraries: criteria and problems from users' perspectives, Library \& Information Science Research, 28, pp.433-452.

Yen, Chia-Hui, (2002), The Application of data mining in library marketing and customer relationship management, Bulletin of Library and Information Science, 42, pp.58-68.

Zimmerman, L. and Milligan, A. T. (2007). Perspectives on communicating with the Net Generation. Innovate 4(2).

http://www.innovateonline.info/index.php?view=artical\&id=338. 


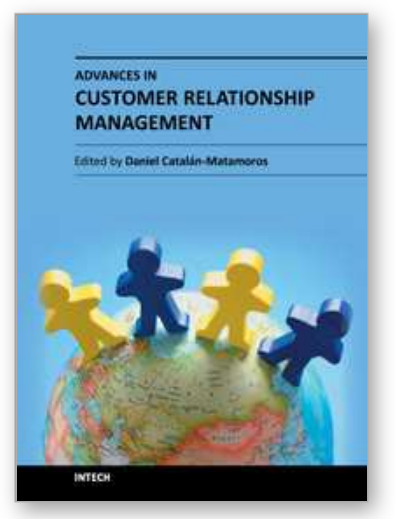

\author{
Advances in Customer Relationship Management \\ Edited by Dr. Daniel Catalan-Matamoros
}

ISBN 978-953-51-0516-9

Hard cover, 146 pages

Publisher InTech

Published online 11, April, 2012

Published in print edition April, 2012

Customer relationship management (CRM) strategies have become increasingly important worldwide due to changes in expectations from customers as well as changes in the nature of markets. This book puts forth a conceptualization that attempts to not only outline CRM's domain but also to reconcile the divergent perspectives found in the academic and popular literature. Readers can see through measurable datacontaining examples how the theory is applied with great success by various real-life examples. This book presents innovative proven methods for determining whether a CRM strategy for changing the way a company provides service (by adding new technology, processes, and procedures) will realize the return on the investment projected. It could be a great help to CRM personnel, student, managers and any one that works directly or indirectly with customers.

\title{
How to reference
}

In order to correctly reference this scholarly work, feel free to copy and paste the following:

Shiow-Luan Wang (2012). Development of a Service Framework for Library Users from Customer Relationship Management Perspective, Advances in Customer Relationship Management, Dr. Daniel Catalan-Matamoros (Ed.), ISBN: 978-953-51-0516-9, InTech, Available from: http://www.intechopen.com/books/advances-incustomer-relationship-management/development-of-a-service-framework-for-library-users-from-customerrelationship-management-perspecti

\section{INTECH}

open science | open minds

\author{
InTech Europe \\ University Campus STeP Ri \\ Slavka Krautzeka 83/A \\ 51000 Rijeka, Croatia \\ Phone: +385 (51) 770447 \\ Fax: +385 (51) 686166 \\ www.intechopen.com
}

\author{
InTech China \\ Unit 405, Office Block, Hotel Equatorial Shanghai \\ No.65, Yan An Road (West), Shanghai, 200040, China \\ 中国上海市延安西路65号上海国际贵都大饭店办公楼 405 单元 \\ Phone: +86-21-62489820 \\ Fax: $+86-21-62489821$
}


(C) 2012 The Author(s). Licensee IntechOpen. This is an open access article distributed under the terms of the Creative Commons Attribution 3.0 License, which permits unrestricted use, distribution, and reproduction in any medium, provided the original work is properly cited. 